\title{
RHEUMATOID ARTHRITIS AND PSORIASIS
}

\author{
BY \\ M. DE G. GRIBBLE \\ North-East Regional Rheumatism Centre, Department of Physical Medicine, The London Hospital
}

(RECEIVED FOR PUBLICATION DECEMBER 9, 1954)

An association between rheumatoid arthritis and psoriasis has been thought to exist for the past 130 years, but its nature is still debatable. There are two main problems:

(i) whether the two conditions coincide more frequently than can be explained by chance,

(ii) whether "psoriatic arthritis" is a specific disease.

COINCIDENCE OF THE Two Conditions

(i) Occurrence of Psoriasis amongst Rheumatoid Arthritics.-The reports available in the English language from Scandinavia or from the U.S.A. are $\vec{\circ}$ listed in Table I. Although few series are large, their uniformity is striking, and it appears that in both countries some 3 per cent. of all rheumatoid arthritics also suffer from psoriasis. Some of these authors also give the incidence of psoriasis in a control series; these estimates, together with those available for the general population, are shown in Table II; from this it appears that the normal incidence of psoriasis is less than 1 per cent.

TABLE I

OCCURRENCE OF PSORIASIS IN RHEUMATOID ARTHRITICS

\begin{tabular}{|c|c|c|c|c|c|c|c|c|c|c|}
\hline \multirow{2}{*}{\multicolumn{6}{|c|}{ Author }} & \multirow{3}{*}{$\begin{array}{l}\text { Date } \\
1935\end{array}$} & \multirow{3}{*}{$\begin{array}{c}\text { Place } \\
\text { Rochester, Minn. }\end{array}$} & \multirow{3}{*}{$\begin{array}{c}\begin{array}{c}\text { Total Cases with } \\
\text { Rheumatoid } \\
\text { Arthritis }\end{array} \\
65\end{array}$} & \multicolumn{2}{|c|}{ With Psoriasis } \\
\hline & & & & & & & & & \multirow{2}{*}{ Number } & \multirow{2}{*}{$\frac{\text { Percentage }}{4 \cdot 6}$} \\
\hline Hench & . & $\ldots$ & . & $\ldots$ & . & & & & & \\
\hline \multicolumn{3}{|c|}{ Dawson and Tyson } & . & . & . & 1938 & New York & 1,000 & 26 & $2 \cdot 6$ \\
\hline \multicolumn{4}{|c|}{ Bauer, Bennett, and Zeller } & . & . & 1941 & Boston, Mass. & 300 & 8 & $2 \cdot 7$ \\
\hline Heinild & $\ldots$ & $\ldots$ & $\ldots$ & . & 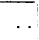 & 1942 & Denmark & $27 !$ & 8 & $3 \cdot 0$ \\
\hline Wassma & & $\ldots$ & . & . & $\cdots$ & 1949 & Sweden & 1,000 & 31 & $3 \cdot 1$ \\
\hline Cecil & $\ldots$ & $\ldots$ & $\ldots$ & . & $\ldots$ & 1949 & New York & 930 & 53 & $5 \cdot 6$ \\
\hline
\end{tabular}

TABLE II

OCCURRENCE OF PSORIASIS IN CONTROLS

\begin{tabular}{|c|c|c|c|c|c|c|c|c|c|c|c|}
\hline \multirow{2}{*}{\multicolumn{6}{|c|}{ Author }} & \multirow{2}{*}{ Date } & \multirow{2}{*}{ Place } & \multirow{2}{*}{ Description } & \multirow{2}{*}{$\begin{array}{c}\text { Total } \\
\text { Number of } \\
\text { Subjects }\end{array}$} & \multicolumn{2}{|c|}{ With Psoriasis } \\
\hline & & & & & & & & & & Number & Percentage \\
\hline \multicolumn{3}{|c|}{ Dawson and Tyson } & . & . & .. & 1938 & New York & Osteoarthritics & $>1,000$ & 3 & $<\mathbf{0 \cdot 3}$ \\
\hline \multicolumn{3}{|c|}{ Bauer and others } & $\ldots$ & . & .. & 1941 & Boston, Mass. & Unspecified & 300 & 2 & $0 \cdot 7$ \\
\hline Heinild & $\ldots$ & $\ldots$ & $\ldots$ & $\ldots$ & . & 1942 & Denmark & $\begin{array}{l}\text { Arthroses other than } \\
\text { rheumatoid arthritis }\end{array}$ & 270 & 0 & 0 \\
\hline Gahan & . & . & . & . & . & 1943 & New York & General population & & & $\begin{array}{c}\text { At least } \\
1 \cdot 0\end{array}$ \\
\hline \multirow{2}{*}{ Romanus } & & & 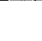 & . & 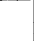 & 1945 & \multirow{3}{*}{ Sweden } & Mental in-patients & 132,675 & 137 & $0 \cdot 1$ \\
\hline & $\cdots$ & $\cdots$ & $\cdots$ & $\cdots$ & $\cdot$ & 1943 & & Male conscripts & 1,987 & 2 & $0 \cdot 1$ \\
\hline Forssman & . & . & . & $\cdots$ & .. & 1947 & & Psychiatric patients & 693 & 10 & 1.4 \\
\hline \multicolumn{2}{|l|}{ Wassmann } & . & . & . & .. & 1949 & Sweden & $\begin{array}{l}\text { General medical out- } \\
\text { patients }\end{array}$ & 10,000 & 43 & $0 \cdot 4$ \\
\hline Ingram & . & . & . & $\ldots$ & .. & 1954 & England & General population & & & $1-2$ \\
\hline
\end{tabular}


Thus, in both the U.S.A. and Scandinavia, psoriasis seems to be about three times as common in rheumatoid arthritics as in the rest of the population. Reiter and Nørholm-Pedersen (1953) alone disagree, stating that psoriasis was no more frequent in polyarthritis than in other forms of arthritis, but their figures are so inconsistent that it is difficult to follow their reasoning.

(ii) Occurrence of Arthritis amongst Psoriatics.The reports available in English are collected in Table III, but unlike those already quoted, are extremely variable. Psoriasis is a definitive disease, whereas "arthritis" is a generic term, and its incidence in psoriatics depends on its definition; in Table III this varies from asking patients whether they had ever suffered from "arthritis" and recording the answers without clinical confirmation (Lane and Crawford, 1937), to a strict definition of "psoriatic arthritis" (Epstein, 1939). No conclusion about the incidence of rheumatoid arthritis amongst psoriatics can therefore be drawn from these reports.
Romanus (1945), in a more specific report, found that $2 \cdot 2$ per cent. of a series of psoriatics developed a polyarthritis severe enough to require admission to hospital, but after calculating the risk of being admitted to hospital for polyarthritis among the whole population, he concluded that "no increased risk of developing chronic polyarthritis is found for psoriatic patients".

Investigation.- - An attempt was made to estimate the incidence of psoriasis in all the rheumatoid arthritics who attended the Department of Physical Medicine at The London Hospital during the last three months of 1953 . The major disability in those with both diseases was the arthritis, and since no rheumatoid arthritic is ever discharged, it is unlikely that those who also had psoriasis were selected. Only those with a definite diagnosis of rheumatoid arthritis or intermittent hydrarthrosis were included, and in each case the diagnosis of psoriasis was confirmed by a dermatologist.

TABLE III

OCCURRENCE OF ARTHRITIS IN PSORIATICS

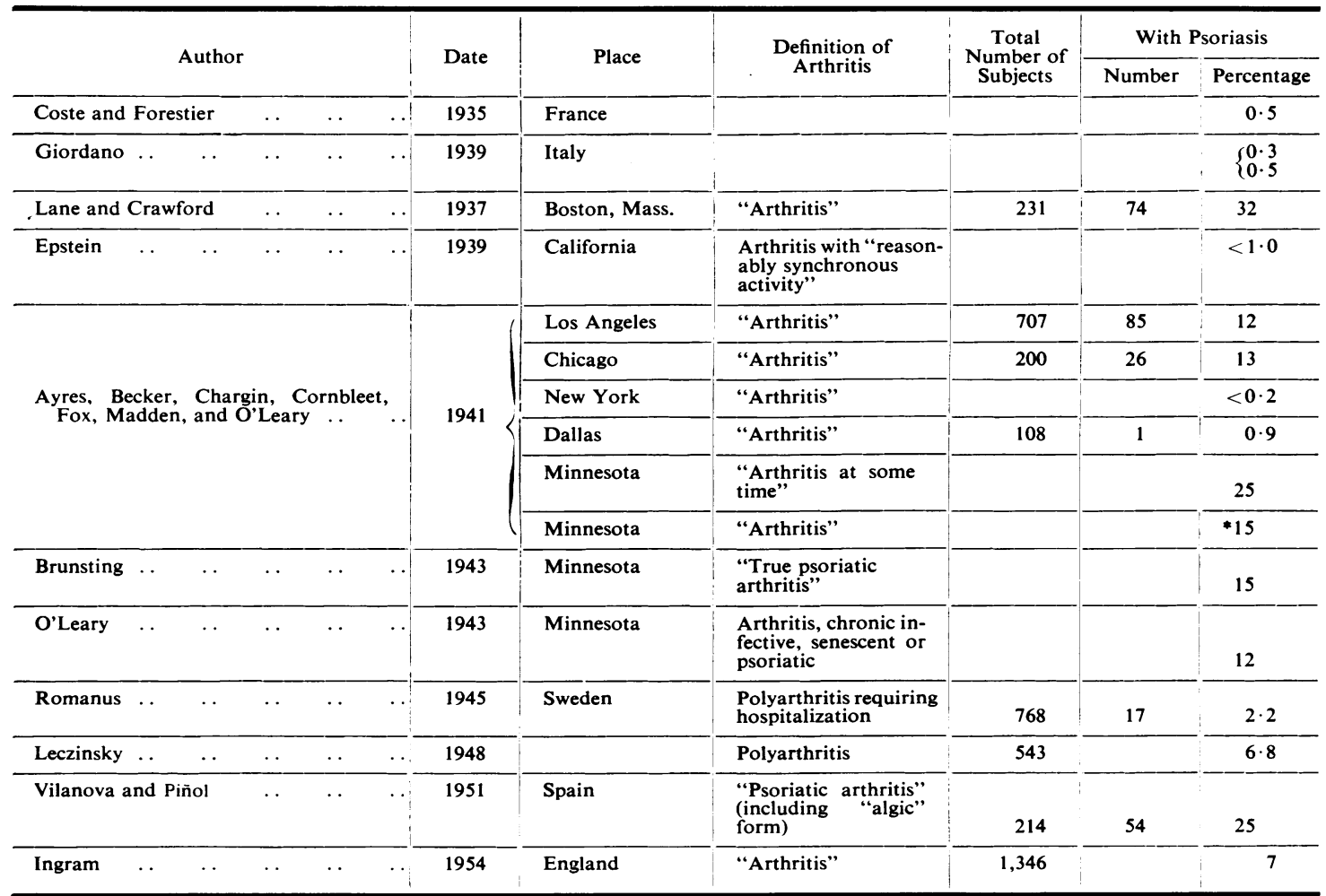

* Including 12 per cent. of infectious and 3 per cent. of psoriatic origin. 
TABLE IV

OCCURRENCE OF PSORIASIS IN RHEUMATOID ARTHRITICS

(PRESENT SERIES)

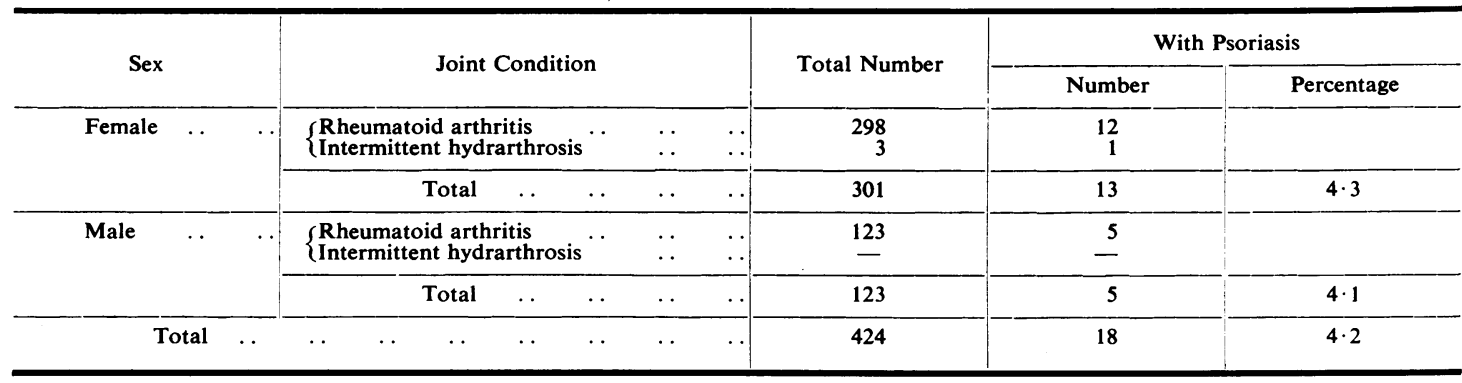

Results.-These are shown in Table IV, where it may be seen that:

(1) The overall incidence of psoriasis was $4 \cdot 2$ per cent.

(2) The incidence in males and females was the same.

However, in some of the psoriatics the arthritis was mild and so limited that it was questionable whether a patient with uncomplicated rheumatoid arthritis of this degree would have attended the department. Even if these cases are omitted, there remain nine psoriatics among 297 female arthritics (3.0 per cent.), and four among 122 male arthritics ( $3 \cdot 3$ per cent.), the mean incidence being $3 \cdot 1$ per cent.

Conclusion.-The Scandinavian and American reports agree that the incidence of psoriasis in rheumatoid arthritis is about 3 per cent., whereas among the rest of the population it is less than 1 per cent.; in this London series also, psoriasis occurred in between 3 and 4 per cent. of all rheumatoid arthritics, both sexes being equally affected.

\section{Is Psoriatic Arthritis a Distinct Disease?}

The term psoriatic arthritis, which has been used to cover a great variety of conditions, should be restricted to describing, first, an arthritis which is characterized by physical signs as well as pain, and secondly one which is "allied to rheumatoid arthritis or one of its sub-varieties, ankylosing spondylitis or Still's disease" (Dawson and Ragan, 1946). Pain alone is not adequate evidence of arthritis, though it has been considered so by Lane and Crawford (1937), Jungmann and Stern (1944) and Vilanova and Piñol (1951), and though the term has been applied to the association of psoriasis with osteo-arthritis (Gibson, 1948; Jeghers and Robinson, 1937; O'Leary, 1943), and gout (Barber, 1938), its occurrence in these conditions is merely coincidence (Dawson and Ragan, 1946).
Having accepted that the incidence of psoriasis in rheumatoid arthritics is greater than in the general population, there remains the problem whether the $\overrightarrow{\vec{A}}$ patient with both diseases has classical rheumatoid in arthritis, or whether the arthritis with psoriasis is $\overrightarrow{\overrightarrow{0}}$ sufficiently different to be classified as "psoriatic $\infty$ arthritis". When the two conditions occur together, 웅 the arthritis "may assume certain unusual charac- teristics" (Dawson and Tyson, 1938), and it is on $\subseteq$ these unusual characteristics that the various $\underset{\mathbb{D}}{\vec{D}}$ definitions of "psoriatic arthritis" have been based $\cdot \vec{\theta}$ Since so many have been suggested and so few agree of it is of interest to consider each of the "unusuक्ष characteristics" in more detail.

(1) The onset of arthritis follows the onset of psoriasis. - Most authorities have found that the onset of arthritis either follows or coincides with that of psoriasis, the psoriasis rarely appearing after the arthritis (Brunsting, 1943; Garrod and Evans, 1924; Graham, 1953; Hench, 1927, 1935; Jungmann and Stern, 1944; Nunemaker and Hartman, 1950; Sherman, 1952; Sterne and Schneider, 1953; Vilanova and Piñol, 1951). However, since psoriasis starts typically before the age of 30 (Vickers, 1950; Romanus, 1945), and the mean age of onset of rheumatoid arthritis is between $\mathbf{4 0}$ and $\mathbf{4 5}$ years (Davidson, 1948; see also below), it follows that the skin condition will normally precede the arthritis, whether or no the two conditions are related. This point is made by Reiter and Nørholm-Pedersen (1953).

(2) The severity of both diseases varies synchronously. This has frequently been noted (Brunsting, 1943; Epstein, 1939; Garrod and Evans, 1924; Gibson, 1948; Graham, 1953; Hench, 1927, 1935; Hunt, 1932; Jeghers o and Robinson, 1937; Nordin, 1934; Nunemaker and $N$ Hartman, 1950; O'Leary, 1943; Vilanova and Piñol, N 1951 ), and it is considered by many to be essential to the $\omega$ diagnosis of "psoriatic arthritis". It has also been found that whereas treatment of the arthritis had no $O$ effect on either condition, treatment of the psoriasis relieved both (Franks and Wallace, 1942; Hench, 1935; Jungmann and Stern, 1944). On the other hand, others found little or no synchronous activity in typical cases 
(Barber, 1938; Clarke, 1950; Sherman, 1952; Wassmann, 1949), whilst Dawson and Tyson (1938) found it in half their cases and Reiter and Norholm-Pedersen (1953) in one-third.

Synchronism is nearly always the patient's subjective impression, so that increased psoriatic activity may merely direct attention to the arthritis, or in common with other diseases, it may increase the arthritic activity, but in each case the parallel fluctuations are probably not an effect specific to psoriasis.

(3) Involvement of the terminal inter-phalangeal joints. -It has been stated that when both diseases co-exist, the terminal inter-phalangeal (TIP) joints of the hands and feet are frequently affected, whereas this is rare in uncomplicated rheumatoid arthritis (Barber, 1938; Bauer, Bennett, and Zeller, 1941; Brunsting, 1943; Gibson, 1948; Graham, 1953; Hench, 1935; Hunt, 1932; Jungmann and Stern, 1944; Mattingly, 1953; Nordin, 1934; Nunemaker and Hartman, 1950; Plenk, 1950; Sherman, 1952; Shlionsky and Blake, 1936; Sterne and Schneider, 1953; Vilanova and Piñol, 1951). This arthritis is frequently associated with psoriasis of the nails, and according to some reports occurs only when the corresponding nail is affected and vice versa (Nunemaker and Hartman, 1950; Plenk, 1950; Sherman, 1952).

It is frequently difficult to distinguish between specific TIP arthritis and Heberden's nodes, for although these are usually a primary condition, they are also the final result of any arthritis of the TIP joints. If a specific arthritis is seen in the acute stage with soft tissue involvement, the diagnosis is clear, but it is far from easy to differentiate the later stages from independent Heberden's nodes. Hench (1935) suggested that TIP arthritis is probably specific if $(a)$ the patient is too young for Heberden's nodes, and $(b)$ the TIP joints of the toes are also affected. Unfortunately, most of the patients in this series were old enough to have developed Heberden's nodes in any case, and the toes of almost every patient seen in the department are so deformed that it is impossible to say whether or no they are involved in a specific arthritis.

Since we are told that in psoriatic arthritis, affection of the TIP joints is typical, it is probable that any form of TIP arthritis in these patients is considered to be part of the syndrome; on the other hand, in uncomplicated rheumatoid arthritis, we are told that these joints are rarely involved, so that TIP arthritis, when found, is considered to be an independent symptom. It is possible, therefore, that the strict association of TIP arthritis with psoriatic, but not rheumatoid, arthritis is not always justified; this is borne out by Bauer and others (1941), who found TIP arthritis frequently in uncomplicated rheumatoid arthritis, by Cecil (1949), who considered that in the presence of psoriasis, TIP arthritis was "accidental", and by the present finding that the incidence of TIP arthritis in this series was little different from that of Heberden's nodes in a control series of uncomplicated rheumatoid arthritics.

(4) Bone destruction.-Arthritis mutilans is usually associated with psoriasis, but does occur without
(Graham, 1953; Jonsson, 1949; Mather, 1954), but lesser degrees of destruction of the bones of the hands and feet have been more specifically associated with psoriasis (Brunsting, 1943; Fawcitt, 1950; Gibson, 1948; Sherman, 1952; Sterne and Schneider, 1953). The destruction affected mainly the distal ends of the bones, and in some cases there was associated widening of the articular surface of the proximal end of the adjoining bone, often with indentation (Fawcitt, 1950; Gibson, 1948). This limited destruction is not recorded in the absence of psoriasis, though presumably it must be a stage in the development of arthritis mutilans, with or without skin involvement.

(5) Reversible nature of arthritis.-Some authors have found that, particularly in the early stages, the arthritis may undergo complete remissions rarely seen in uncomplicated rheumatoid arthritis (Brunsting, 1943; Garrod and Evans, 1924; Graham, 1953; Nordin, 1934; Sherman, 1952). On the other hand, Jungmann and Sterne (1944) state that once affected, the joint never becomes normal again.

(6) Association with intermittent hydrarthrosis.-Barber (1938) and Garrod and Evans (1924) found that psoriasis was often associated with intermittent hydrarthrosis, but later authors have not confirmed this observation.

(7) Sex incidence.-According to Sherman (1952) and Vilanova and Piñol (1951) "psoriatic arthritis" is commoner in males, whereas Epstein (1939) stated that the sex distribution was equal. However, since none of these authors defined the nature or size of the population from which their series were taken, no conclusion can be drawn. Romanus (1945) found that, in each of various reports, the sex distribution of psoriatic arthritis was always the same as that of the rest of the patients seen by each author, and both in the present series and in that of Reiter and Nørholm-Pedersen (1953) the incidence was equal in both sexes.

The disagreement as to which of these unusual characteristics are found in "psoriatic arthritis" is reflected in the many definitions summarized in Table V (overleaf).

Many of these reports are based on single cases or on very small series, so that minor differences might be expected, but no clear picture of even the major features emerges. The greatest agreement is found on the earlier onset of the psoriasis, the distribution of the arthritis, and the frequency of bone destruction; the commonest single feature is arthritis of the TIP joints with associated psoriasis of the corresponding nails, and some would restrict the term "psoriatic arthritis" to cases in which the arthritis is confined to these joints (Bauer and others, 1941; Mattingly, 1953; Nunemaker and Hartman, 1950; Plenk, 1950). Nevertheless, apart possibly from the limited bone destruction, the remaining characteristics are either not specific or subjects of disagreement. 
DESCRIPTIO

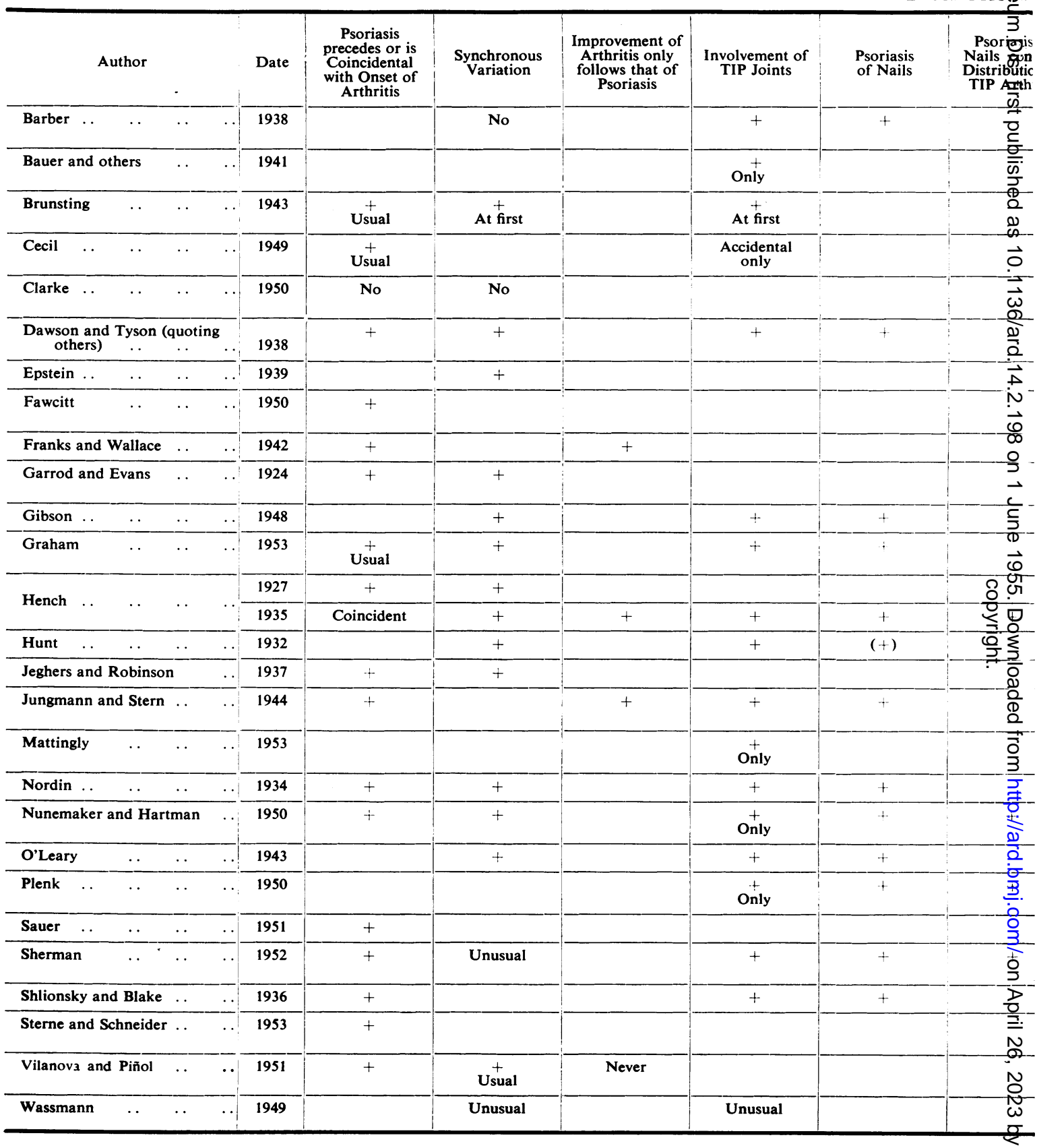

If psoriatic arthritis is to be accepted as a distinct naturally occurring disease, it should be constantly and clearly distinguishable from rheumatoid arthritis, though allied to it; some authors, in describing a series, found that certain patients also had features typical of rheumatoid arthritis, and explained it by suggesting that these patients had both psoriatic and rheumatoid arthritis (Sterne and Schneider, 1953; 


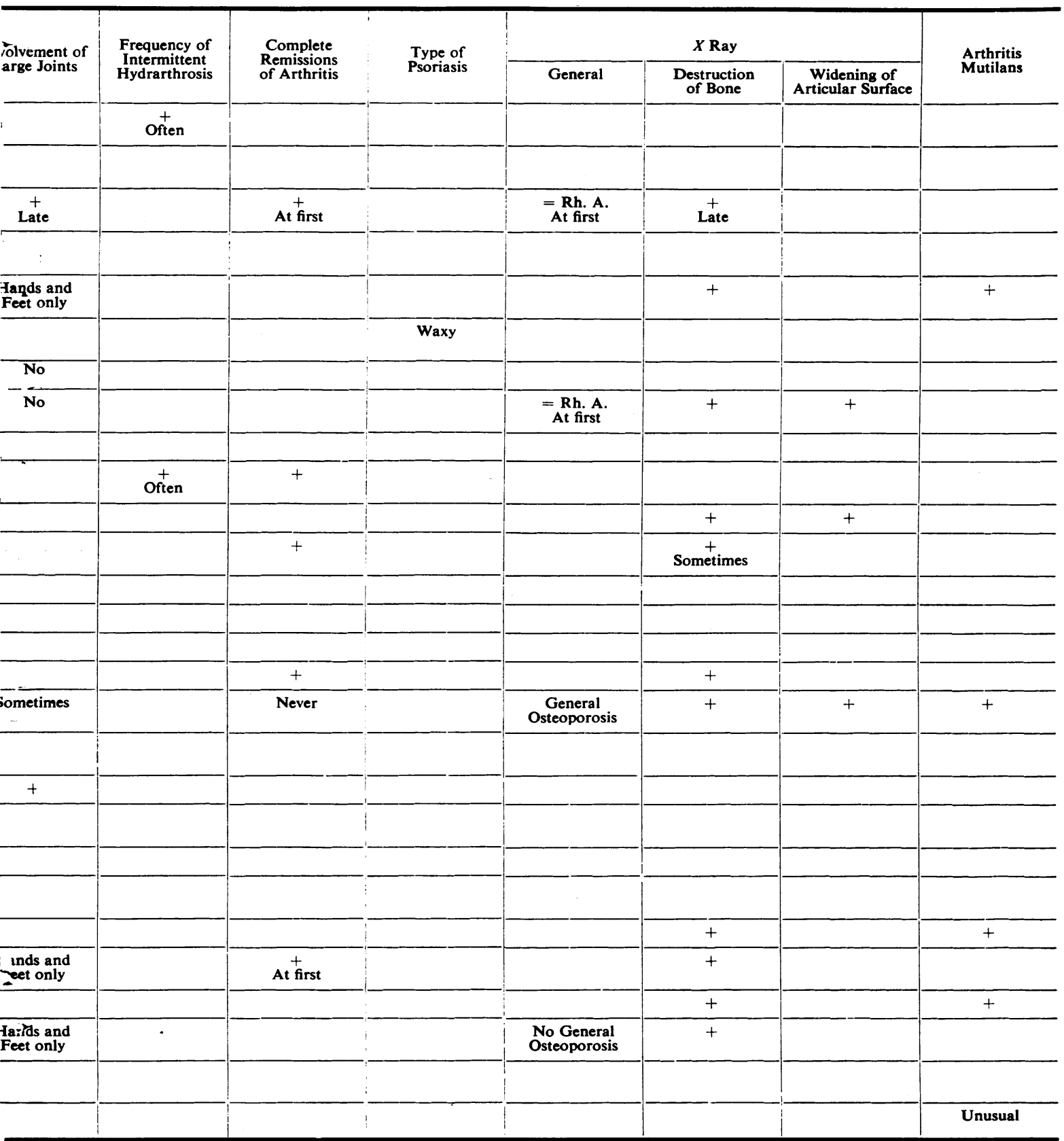

Fawcitt, 1950), but this is too fanciful a concept to form serious evidence for the separate existence of psoriatic arthritis.

It is probable that the desire to distinguish psoriatic arthritis from rheumatoid arthritis originated in the observation that the two conditions were more frequently associated than can be explained by chance. Since the incidence of psoriasis in 
rheumatoid arthritics is about three times that of the general population, then either:

(a) One-third of the cases in which the two diseases co-exist should have unexceptional rheumatoid arthritis (cases of chance association), and the other two-thirds should have a distinct arthritis;

or (b) all cases with both diseases should have the distinct arthritis, i.e. the presence of psoriasis constantly alters the form of the arthritis.

Analysis of this Series.-The series consists of the eighteen cases considered in the first part (Table IV) and two others who first attended in 1954. The characteristics of their disease are considered under the headings used above. Some comparisons have been made with a small control series of 49 women and seventeen men with uncomplicated rheumatoid arthritis.

(1) Time relationship.-Since there are only five men, the series is treated as a whole, and the mean age at onset of arthritis is seen to be $41 \cdot 2$ yrs (Table VI), or, if the mild cases are omitted, 36.4 yrs. In the control series it was $44.9 \pm 1.47 \mathrm{yrs}$ in the women, and $44 \cdot 6 \pm 3 \cdot 12$ yrs in the men, and is thus probably not significantly altered by the presence of psoriasis. It may be calculated from the data given by Reiter and Nørholm-Pedersen
(1953) that the mean age at onset of the arthritis in their psoriatics was $38.6 \mathrm{yrs}$. Although the arthritis appears to start later than the psoriasis, the small difference is not statistically significant. Unless patients had forgotten earlier attacks, or gave a history too vague to diagnose in retrospect, the surprising feature is the late onset of the psoriasis.

(2) Synchronous variation.-Roughly half showed $\frac{}{0}$ synchronous variation, though it was not always constant.

(3) Involvement of TIP joints.-Fig. 1 (opposite) shows $\stackrel{\mathbb{\complement}}{\varrho}$ the distribution of affected joints in all except the five very के mild cases; it is seen that the TIP joints are involved in $\vec{\circ}$ about one-third, but that most other joints of the body, ? except the hip, are involved at least as frequently; there $\overrightarrow{\vec{\omega}}$ was no relative sparing of the metacarpo-phalangeal ${ }_{S}$ joints, as described by Sherman (1952). Fig. 2 (opposite) shows the distribution of affected joints in the control 0 series; some had arthritis of the TIP joints, usually in the $\vec{A}$ form of Heberden's nodes, and this column is only is cross-hatched, whereas in Fig. 1 it is blacked in, regardless $\overrightarrow{\vec{O}}$ of the exact appearance of the joints.

It is striking that the proportion of cases with involvement of these joints is so similar in both the psoriatics and non-psoriatics; moreover the general distribution of the $c$ arthritis is practically identical. Reiter and NørholmPedersen (1953), in a similar study, concluded that there were differences, but the frequency distribution in their $\theta$ psoriatics was almost the same as that in Figs 1 and $8 \mathrm{G}$ while their control series appeared atypical.

TABLE VI

DETAILS OF INDIVIDUAL PATIENTS

(PRESENT SERIES)

\begin{tabular}{|c|c|c|c|c|c|c|c|c|c|c|c|}
\hline $\begin{array}{l}\text { Degree } \\
\text { of } \\
\text { Disease }\end{array}$ & Patients & $\begin{array}{c}\text { Age at } \\
\text { Onset of } \\
\text { Arthritis }\end{array}$ & $\begin{array}{l}\text { Age at } \\
\text { Onset of } \\
\text { Psoriasis }\end{array}$ & $\begin{array}{c}\text { Period by which } \\
\text { Psoriasis pre- } \\
\text { cedes or follows } \\
\quad \text { Arthritis }\end{array}$ & $\underset{\substack{\text { Joints } \\
\text { Involved }}}{\text { Inv }}$ & $\begin{array}{l}\text { OtherSmall } \\
\text { Joints of } \\
\text { Hands } \\
\text { (including } \\
\text { Wrists) } \\
\text { Involved }\end{array}$ & $\begin{array}{c}\text { Large } \\
\text { Joints } \\
\text { Involved }\end{array}$ & $\begin{array}{l}\text { Psoriasis } \\
\text { of Finger } \\
\text { Nails }\end{array}$ & $\begin{array}{c}\text { Syn- } \\
\text { chronous } \\
\text { Variation }\end{array}$ & $\begin{array}{l}\text { Bone } \\
\text { Destruc- } \\
\text { tion } \\
\text { in Hands }\end{array}$ & $\begin{array}{c}\text { Radio- } \\
\text { logical } \\
\text { Widening } \\
\text { of Articular } \\
\text { Margin }\end{array}$ \\
\hline \multirow[t]{3}{*}{ Severe } & $\begin{array}{r}1 \\
2 \\
3 \\
4 \\
4 \\
5 \\
6 \\
+7 \\
8 \\
* 9 \\
10\end{array}$ & $\begin{array}{l}30 \\
25 \\
40 \\
59 \\
69 \\
21 \\
18 \\
54 \\
24 \\
50\end{array}$ & $\begin{array}{l}23 \\
14 \\
38 \\
61 \\
58 \\
21 \\
22 \\
67 \\
40 \\
50\end{array}$ & $\begin{array}{c}7 \text { yrs } \\
11 \\
2 \\
-2 \\
11 \\
\text { A few weeks } \\
-4 \text { yrs } \\
-13 \\
-16 \\
\text { A few months }\end{array}$ & $\begin{array}{l}+ \\
+ \\
- \\
- \\
+ \\
+ \\
- \\
+ \\
+\end{array}$ & $\begin{array}{l}+ \\
\dot{+} \\
+ \\
- \\
\dot{+} \\
+ \\
\therefore \\
\dot{-} \\
\dot{+} \\
+\end{array}$ & $\begin{array}{l}+ \\
+ \\
+ \\
+ \\
+ \\
+ \\
+ \\
+ \\
+ \\
+\end{array}$ & $\begin{array}{l}+ \\
\dot{+} \\
- \\
\vdots \\
\pm \\
\pm \\
\dot{t} \\
+ \\
+ \\
+\end{array}$ & $\begin{array}{l}- \\
- \\
+ \\
- \\
+ \\
+ \\
+ \\
+ \\
-\end{array}$ & $\begin{array}{l}- \\
+ \\
- \\
- \\
- \\
- \\
\cdots \\
\cdots \\
+\end{array}$ & $\begin{array}{l}\overline{+} \\
\overline{-} \\
\overline{-} \\
\overline{+} \\
\overline{+} \\
+\end{array}$ \\
\hline & $\begin{array}{ll} & 11 \\
\text { Men: } & 12 \\
& 13 \\
& 14\end{array}$ & $\begin{array}{l}30 \\
18 \\
30 \\
37\end{array}$ & $\begin{array}{l}33 \\
17 \\
30 \\
35\end{array}$ & $\begin{array}{c}-3 \text { yrs } \\
1 \\
\text { Coincidental } \\
2 \text { yrs }\end{array}$ & $\begin{array}{l}+ \\
+ \\
+\end{array}$ & $\begin{array}{l}+ \\
\dot{+} \\
+\end{array}$ & $\begin{array}{l}+ \\
+ \\
+ \\
+\end{array}$ & $\begin{array}{l}- \\
-\dot{-} \\
--\end{array}$ & $\begin{array}{l}+ \\
+ \\
+ \\
-\end{array}$ & $\begin{array}{l}-+ \\
-1 \\
-1 \\
-\end{array}$ & $\begin{array}{l}+ \\
\pm \\
+\end{array}$ \\
\hline & Total & $\begin{array}{r}36 \cdot 4 \\
\pm 4 \cdot 23\end{array}$ & $\begin{array}{c}36 \cdot 1 \\
\pm 4 \cdot 62\end{array}$ & & & & & & & & \\
\hline \multirow[t]{2}{*}{ Mild } & $\begin{array}{r}15 \\
16 \\
\text { Women: } 17 \\
18 \\
19\end{array}$ & $\begin{array}{l}64 \\
56 \\
49 \\
49 \\
43\end{array}$ & $\begin{array}{l}17 \\
53 \\
32 \\
45 \\
43\end{array}$ & $\begin{array}{c}47 \text { yrs } \\
3 \\
17 \\
-\quad 4 \\
\text { A few weeks }\end{array}$ & $\begin{array}{l}- \\
- \\
- \\
-\end{array}$ & $\begin{array}{l}+ \\
+ \\
+ \\
+ \\
+\end{array}$ & $\begin{array}{l}- \\
- \\
- \\
- \\
+\end{array}$ & $\begin{array}{l}- \\
+ \\
- \\
-\end{array}$ & $\begin{array}{l}- \\
+ \\
+ \\
- \\
-\end{array}$ & $\begin{array}{l}- \\
-- \\
- \\
-\end{array}$ & $\begin{array}{l}- \\
- \\
- \\
-\end{array}$ \\
\hline & Men: $\quad 20$ & 57 & 51 & 6 yrs & - & + & - & - & - & $\cdots$ & - \\
\hline \multicolumn{2}{|c|}{ All Cases } & $\begin{array}{r}41 \cdot 2 \\
\pm 3 \cdot 59\end{array}$ & $\begin{array}{c}37 \cdot 5 \\
\pm 3 \cdot 53\end{array}$ & & & & & & & & \\
\hline
\end{tabular}



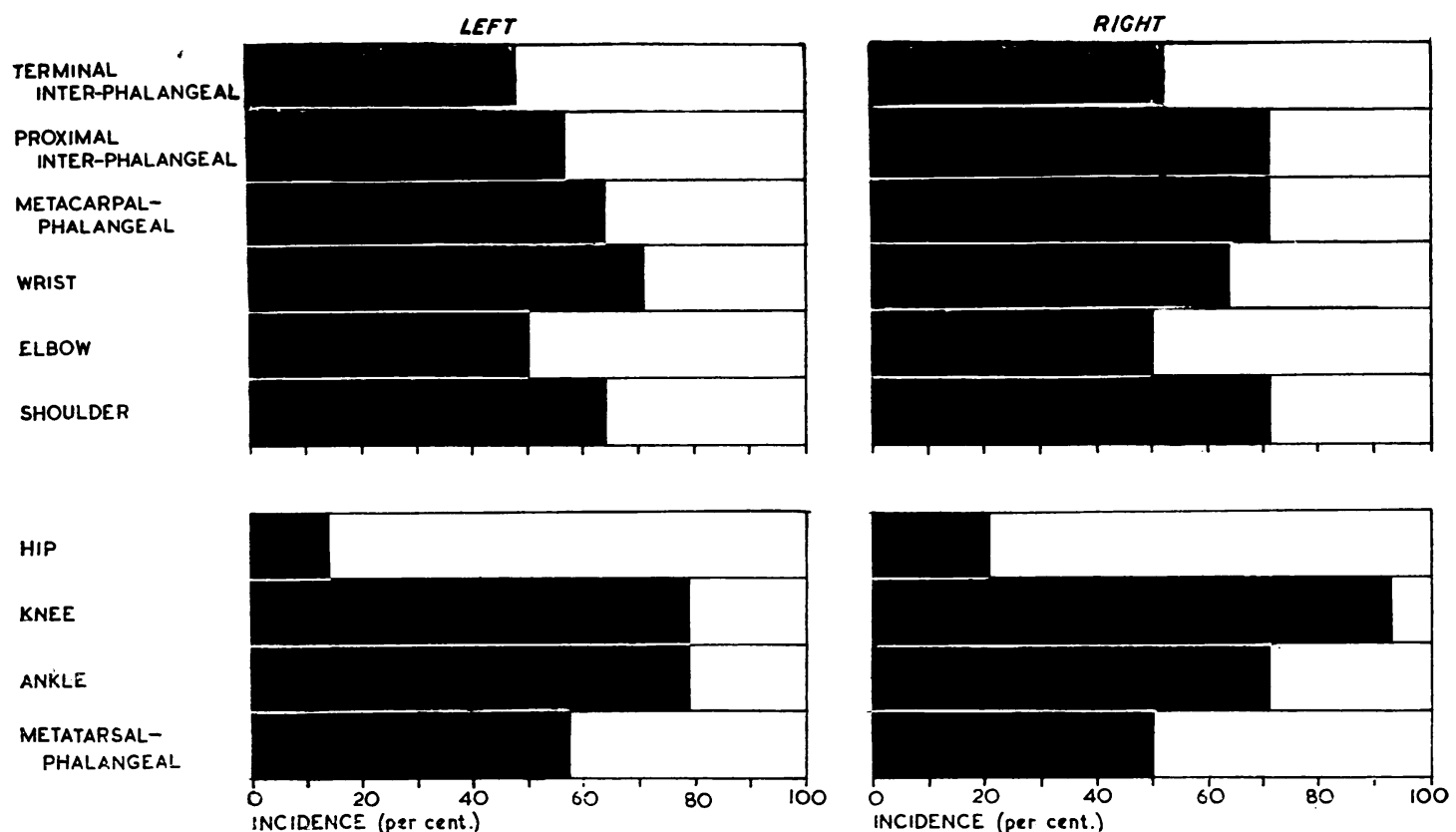

Fig. 1.-Distribution of arteries in fourteen severe rheumatoid arthritics with psoriasis Blocks indicate percentage number of patients with involvement of each joint.
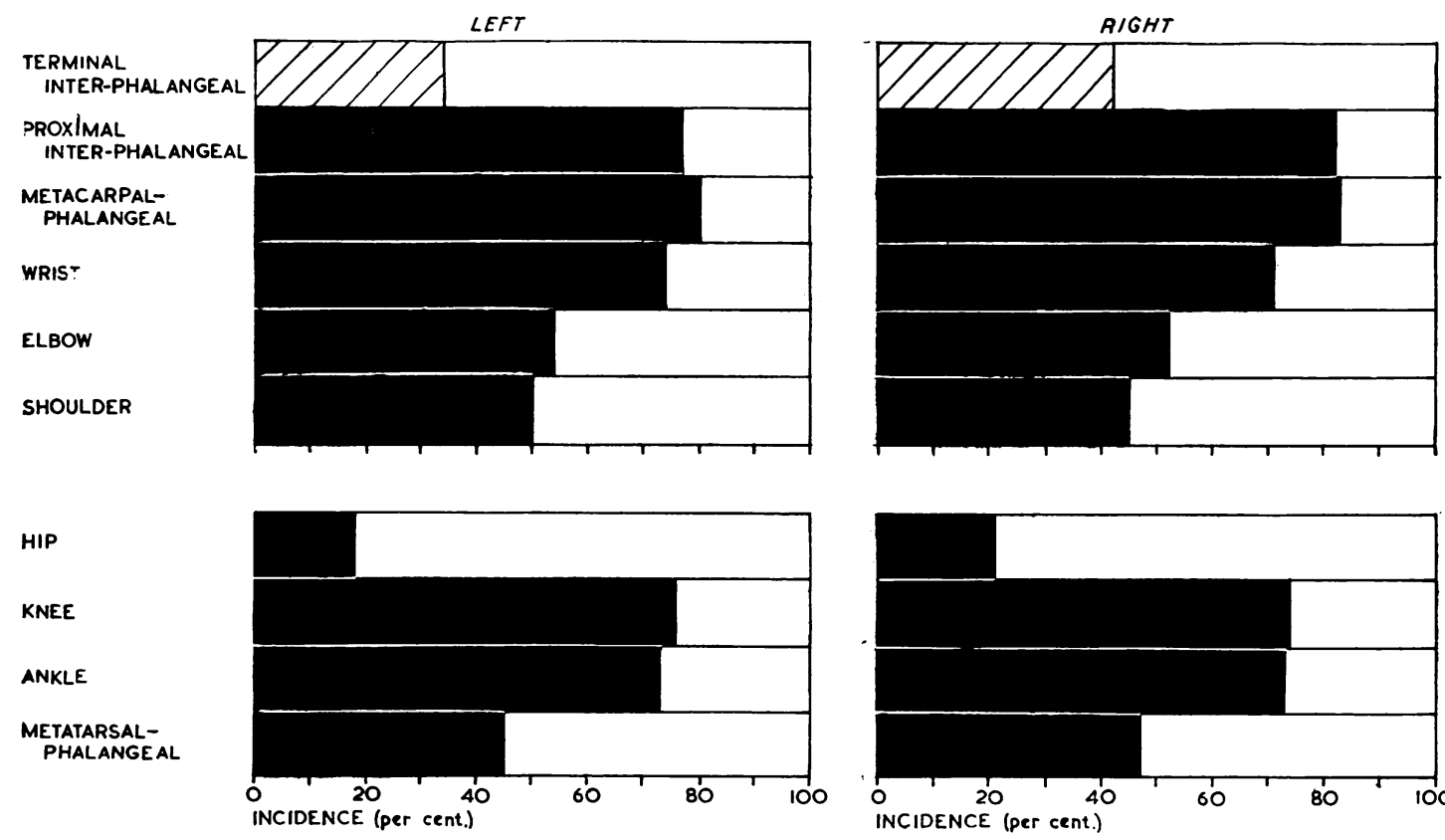

Fig. 2.-Distribution of arthritis in 66 uncomplicated rheumatoid arthritics. Blocks indicate percentage number of patients with involvement of each joint.

(4) Bone destruction.-Five cases (one-third of the series, after discounting the mild cases) showed radio- logical destruction of the long bones of the hands, whereas no destruction was found clinically in the controls. 
(5) Reversible nature of arthritis.-The period of observation was too short to observe this, but it was not mentioned in any history, and is not therefore a comparable feature.

(6) Association with intermittent hydrarthrosis.-In this series (Table IV) no man had this condition, but it was seen in three of the 301 women in the non-psoriatic group, and one in the nine psoriatics; both groups are too small to make this apparent difference significant.

No case of psoriasis was seen in 33 men and ten women attending with ankylosing spondylitis.

(7) Sex incidence.-Three times as many women were seen as men, and in both sexes the incidence of psoriasis was between 3 and 4 per cent.

\section{Discussion}

If "psoriatic arthritis" were a naturally occurring disease distinct from rheumatoid arthritis, one would expect at least two-thirds of this series to show a uniform pattern clearly distinguishable from that of rheumatoid arthritis, but this is far from being the case. Nor do any of the arthritic patterns (Table VI) satisfy the criteria suggested for "psoriatic arthritis". Whenever the TIP joints appeared to be involved, other small joints of the hands were also affected, and usually some of the large joints elsewhere as well, nor was the distribution of the arthritis appreciably different from that of uncomplicated rheumatoid arthritis. Half showed some synchronous variation, but it was often neither striking nor exact. The two most characteristic features were the high incidence of bone destruction, and the high frequency of psoriasis of the nails, though this was by no means necessarily associated with arthritis of the corresponding TIP joint.

In Table VII the incidence of the main characteristics in this series is compared with that in the only other unselected series, and there is fair agreement except that there is no mention of bone destruction. It seems possible, therefore, that the high incidence of bone destruction in the present series is not strictly representative, and that this character should not be considered the distinctive feature of a distinct $\frac{D^{\circ}}{\frac{1}{3}}$ "psoriatic arthritis" without further confirmation.

\section{Conclusion}

It does not appear justifiable to consider "psoriatic $\underset{\overrightarrow{\mid}}{\vec{A}}$ arthritis" as a distinct naturally occurring syndrome. $\frac{\text { ? }}{?}$ The descriptions that have been suggested are based on certain arbitrarily selected characteristics, but $\frac{\bar{\sigma}}{\bar{D}}$ since no single one can account for the excess of $\frac{\bar{\Phi}}{\sigma}$ rheumatoid arthritics who also have psoriasis, they $\supseteq$ appear to serve no useful purpose. One must in therefore conclude, as did Dawson and Tyson (1938) $\vec{\circ}$ that the most that can reasonably be claimed is that rheumatoid arthritics seem to be unusually prone to $\vec{\omega}$ psoriasis, and that when they have both diseases, the arthritis may often take one of its less usualo forms; the commonest of these is bony destruction $\vec{A}$ in the hands, the psoriasis also appears unusual in i its late onset, and in the high incidence of nail $\vec{\infty}_{\infty}$ involvement.

Since the term "psoriatic arthritis" varies so을 widely in its meaning from one writer to another, $\vec{c}$ it should be discarded, but, in recognition of the peculiar frequency with which psoriasis occurs in $ه$ rheumatoid arthritics and the unusual forms that the $\overrightarrow{0}$ arthritis may take, it would be well always to specify or that the patient suffering from both diseases hes "rheumatoid arthritis with psoriasis".

\section{Summary}

(1) The incidence of psoriasis in a series of $\frac{\mathbb{Q}}{\alpha}$ rheumatoid arthritics was found to be between $\overrightarrow{\overrightarrow{0}}$ 3 and 4 per cent.

(2) This incidence was the same in both men and women.

(3) In the presence of psoriasis, the arthritis may assume unusual forms, but these are too variable to permit the designation of a "psoriatic" as opposed to "rheumatoid" arthritis.

(4) It is recommended that the term "psoriatic arthritis" be dropped.

TABle VII

SPECIAL CHARACTERISTICS OF RHEUMATOID ARTHRITIS WITH PSORIASIS

\begin{tabular}{|c|c|c|c|c|c|c|}
\hline \multirow[b]{2}{*}{ Author } & \multirow{2}{*}{$\therefore$} & \multirow[b]{2}{*}{ Date } & \multicolumn{3}{|c|}{ Percentage showing } & \multirow{2}{*}{$\begin{array}{l}\text { Total Number } \\
\text { of Cases }\end{array}$} \\
\hline & & & $\underset{\text { Arthritis }}{\text { TIP }}$ & $\begin{array}{c}\text { Synchronous } \\
\text { Variation }\end{array}$ & $\begin{array}{l}\text { Psoriasis } \\
\text { of Nails }\end{array}$ & \\
\hline Dawson and Tyson & .. & 1938 & 23 & 54 & 69 & 26 \\
\hline Bauer and others & $\ldots$ & 1941 & 62 & - & 77 & 26 \\
\hline Reiter and Nørholm & lersen & 1953 & - & 31 & - & 111 \\
\hline \multirow{2}{*}{\multicolumn{2}{|c|}{ Present Series }} & Complete & 35 & 40 & 65 & 20 \\
\hline & & Restricted & 50 & 43 & 64 & 14 \\
\hline
\end{tabular}


My thanks are due to Dr. W. S. Tegner, Director of the Department of Physical Medicine, for his help and encouragement.

\section{REFERENCES}

Ayres, S., Becker, S. W., Chargin, L., Cornbleet, T., Fox, E. C., Madden, J. F., and O'Leary, P. A. (1941). J. invest. Dermat., 4, 399

Barber, H. W. (1938). Proc. roy. Soc. Med., 31, 701

Bauer, W., Bennett, G. A., and Zeller, J. W. (1941). Trans. Ass. Amer. Phys., 56, 349.

Brunsting, L. A. (1943). J. Mich. St. Med. Soc., 42, 546

Cecil, R. L. (1949). Ouoted in "Tenth Rheumatism Review", ed. W. D. Robinson (1953). Ann. intern. Med., 39, 757.

Clarke, O. (1950). Lancet, 1, 249

Clarke, O. (1950). Lancet, 1, 249. Acta derm.-venereol. (Stockh.), 26, suppl. 12.

Davidson, L. S. P. (1948). In "Textbook of the Rheumatic Diseases", ed. W. S. C. Copeman. Livingstone, Edinburgh

Dawson, M. H., and Tyson, T. L. (1938). Trans. Ass. Amer. Phys., 53, 303.

- - and Ragan, C. (1946). In “Nelson's Loose-leaf Medicine”, vol. 5, p. 605. New York.

Epstein, E. (1939). Arch. Derm. Syph. (Chicago), 40, 547.

Fawcitt, J. (1950). Brit. J. Radiol., 23, 440.

Forssman, H. (1947). Ouoted by Reiter and Nørholm-Pedersen (1953). Acta derm-venereol (Stockh.), 33, 372

Franks, A. G., and Wallace, J. J. (1942). Military Surg., 91, 199

Gahan, E. (1943). Arch. Derm. Syph. (Chicago), 48, 305.

Garrod, A., and Evans, G. (1924). Quart. J. Med., 17, 171.

Gibson, H. J. (1948). In "Textbook of the Rheumatic Diseases", ed. W. S. C. Copeman. Livingstone, Edinburgh.

Giordano, C. (1939). Quoted by Romanus (1945). Acta derm.venereol. (Stockh.), 26, suppl. 12.

Graham. W. (1953). In "Comroe's Arthritis", 5th ed., ed. J. L. Hollander, p. 164. Lea and Febiger, Philadelphia.

Heinild, S. (1942). Quoted by Wassmann (1949). Annals of the Rheumatic Diseases, 8, 70.

Hench, P. S. (1927). Proc. Mayo Clin., 2, 89

_- (1935). In "Nelson Loose-leaf Living Surgery”, vol. 3, p. 104. New York.

Hunt, E. (1932). Proc, roy. Soc. Med., 25, 1034.

Ingram, J. T. (1954). Brit. med. J., 2, 823.

Jeghers, H., and Robinson, L. J. (1937). J. Amer. med. Ass., 108, 949.

Jonsson, E. (1949). Annals of the Rheumatic Diseases, 8, 72.

Jungmann, H., and Stern, V. S. (1944). Brit. J. Radiol., 17, 383.

Lane, C. G., and Crawford, G. M. (1937). Arch. Derm. Syph. (Chicago), 35, 1051

Leczinsky, C. G. (1948). Quoted by Reiter and Nørholm-Pedersen (1953). Acta derm.-venereol. (Stockh.), 33, 372

Mather, H. G. (1954). Proc. roy. Soc. Med., 47, 457.

Mattingly, S. (1953). Ann. phys. Med., 1, 264.
Nordin, G. (1934). Acta derm.-venereol. (Stockh.), 15, 221. Nunemaker, J. C., and Hartman, S. A. (1950). Ann. intern. Med.,

O'Leary, P. A. (1943). Canad. med. Ass. J., 48, 34.

Plenk, H. P. (1950). Amer. J. Roentgenol., 64, 635.

Reiter, H. F. H., and Nørholm-Pedersen, A. (1953). Acta derm.venereol. (Stockh.), 33, 372.

Romanus, T. (1945). Ibid., 26, suppl. 12.

Sauer, G. C. (1951). Arch. Derm. Syph. (Chicago), 64, 511.

Sherman, M. S. (1952). J. Bone Jt Surg., 34A, 831.

Shlionsky, H., and Blake, F. G. (1936). Ann. intern. Med., 10, 537.

Sterne, E. H., and Schneider, B. (1953). Ibid., 38, 512

. ed. G. B. Mitchell-Heggs, p. 241. Butterworth, London.

Vilanova, X., and Piñol, J. (1951). Rheumatism, 7, no. 1, p. 197.

Wassmann, K. (1949). Annals of the Rheumatic Diseases, 8, 70.

\section{Arthrite rhumatismale et psoriasis \\ RÉSUMÉ}

(1) On a trouvé que la fréquence du psoriasis dans une série des cas d'arthrite rhumatismale était de 3 à 4 pour cent

(2) La fréquence était la même chez les hommes et les femmes.

(3) En présence du psoriasis, l'arthrite peu revêtir des formes peu habituelles, mais si variables qu'on ne peut pas opposer l'arthrite "psoriasique" à la "rhumatismale".

(4) On recommande l'abandon du terme "arthrite psoriasique".

\section{Artritis reumatoide y psoriasis SUMARIO}

(1) Se determinó la frecuencia de psoriasis en una serie de casos de artritis reumatoide, siendo esta de un 3 a 4 por ciento.

(2) Esta frecuencia dué la misma en ambos sexos.

(3) En presencia de soriasis, la artritis pueded asumir formas poco habituales pero tan variables que no se puede oponer una artritis "psoriásica" a la reumatoide.

(4) Se aconseja el abandono del término "artritis psoriásica . 